\title{
MODELLING THE IMPACT OF LAND COVER CHANGES ON FLOOD MITIGATION IN THE UPPER LUŽNICE BASIN
}

\author{
VĚRA VÁŇOVÁ, JAKUB LANGHAMMER \\ Charles University in Prague, Faculty of Science, Department of Physical Geography and Geoecology. Albertov 6, \\ 12843 Prague 2, Czech Republic; Mailto: vera.vanova@natur.cuni.cz; jakub.langhammer@natur.cuni.cz
}

\begin{abstract}
The study presented herein investigates the impact of simulated changes in land cover on rainfall-runoff conditions for the transboundary basin of the upper Lužnice. The HEC-HMS hydrological model was chosen for these simulations. Scenario models were used to simulate the impact of modifications in basin land cover with individual scenarios reflecting ground cover changes. The years 1990 and 2000, which are available in the CORINE Landcover database, were chosen as variants of river basin land cover. In addition, two theoretical versions of possible extreme variants in fundamental land cover changes - the conversion from agricultural land to grassland and the forestation of the river basin, with the exception of roads and bodies of water - were also included.

Single day rainfall totals with a recurrence period of 10, 20, 50 and 100 years were selected to calculate the volume of runoff and culmination discharge. These results demonstrate a clear decrease in the degree of impact of land cover structure on runoff conditions, increasing with the magnitude of precipitation.
\end{abstract}

KEY WORDS: Land Cover, Flood Mitigation, Retention, Modelling, HEC-HMS.

Věra Váňová, Jakub Langhammer: MODELOVÁNÍ VLIVU ZMĚN KRAJINNÉHO KRYTU NA PRŮBĚH POVODNÍ V POVODÍ HORNÍ LUŽNICE. J. Hydrol. Hydromech., 59, 2011, 4; 24 lit., 7 obr., 2 tab.

Článek představuje výsledky simulace vlivu změn krajinného krytu na srážko-odtokové poměry v přeshraničním povodí horní Lužnice. Pro modelování byl vybrán hydrologický model HEC-HMS. K modelování vlivu změn krajinného pokryvu povodí byla použita metoda scénářového modelování, kde se v jednotlivých scénářích mění krajinný pokryv. Jako varianty krajinného pokryvu povodí byly zvoleny roky 1990 a 2000, pro které je k dispozici databáze CORINE Landcover, a dále dvě teoretické krajní varianty možných variant změn struktury krajinného krytu - zatravnění zemědělské půdy a zalesnění povodí kromě intravilánů, komunikací a vodních ploch.

Pro výpočet objemů odtoků a kulminačních průtoků byly vybrány jednodenní návrhové srážkové úhrny s pravděpodobností opakování 10, 20, 50 a 100 let. Z výsledků simulace je zřejmý pokles vlivu struktury krajinného pokryvu na odtokové poměry se vzrůstající extremitou srážky.

KLÍČOVÁ SLOVA: využití území, krajinný kryt, povodně, retence, modelování, HEC-HMS.

\section{Introduction}

The influence of land use and the associated impact on flood processes has become a subject of great interest to researchers in this area during the past two decades. Data regarding the impact of various modifications on landscape and river network on runoff processes are currently available in the review by Calder (1993) and a documented series of case studies on various geographic environments (Brath, Montanari, and Moretti, 2006; Naef, Scherrer, and Weiler, 2002; Tu, Hall, de
Laat, and de Wit, 2005). Various approaches have been utilized to analyze the effects of land use changes on runoff and flooding. These include the analysis of empirical data and mathematical models, which are dominant in current hydrological research, particularly in combination with GIS tools. The selection and method of applying a specific modelling tool is concurrently influenced by a number of factors. These key factors represent the characteristics of the modelling process, the degree of causality, the extent of temporal and spatial discrimination in the processes and the specific char- 
acteristics of the assessed environment (Becker and Serban, 1990; Kulhavý and Kovár̆, 2002).

The current integration of hydrological models with GIS allows for questions to be addressed on the spatial distribution of input values and parameters using geostatistic methods (Hellweger and Maidment, 1999). Therefore, the potential of each instrument can be explored fully and applied in borderline or atypical conditions.

This paper addresses the role of land use changes in flood protection and the limits of flood mitigation by means of non-structural measures. This research focused on evaluating the effect of changes in land use patterns on the course of basin flooding with a heterogeneous composition of physiographic and socioeconomic conditions.

The modelled area is the upper basin of the Lužnice, which covers a total of 942.5 sq. $\mathrm{km}$ in the territory of Austria and the Czech Republic. The upper part of the basin is situated in the Novohradské Mountains and determines the formation and timing of runoff in the whole Lužnice basin during episodes of extreme precipitation. Due to the low occurrence of agriculture and high share of forest cover in this area, this basin serves as a model area for testing the potential effect of land use change in mitigating flood events.

This study involved two real land use patterns in the basin from 1990 and 2000 and two theoretical scenarios that represented extreme land use patterns, which reinforce the retention potential of the conversion of arable land to grassland and the forestation of the basin. The effect of land use changes was tested on design flood waves resulting from 10 , 20, 50 and 100 year rainfall events.

\section{Study area}

\subsection{Upper Lužnice River basin}

The study area is comprised of the upper Lužnice basin to the Pilař gauging station. The source and upper segment of the Lužnice basin are situated in Austria and the lower part is in the Czech Republic (Fig. 1). From the upper Lužnice basin to the Pilař station covers 942.5 sq. $\mathrm{km}(70.7 \%$ of the area lies in Austria) and the length of the stream is $81.5 \mathrm{~km}$ (VÚV, 2008).

The upper Lužnice River passes through three different physiographical regions: an area with springs located high in the Novohradské Mountains, a highlands area in Austria and a lowland region of the Třebon basin in the Czech Republic.
These areas exhibit different geomorphologic characteristics, geological substrates, climates and they also differ in the nature of land use, which affects runoff conditions (Prach, Jenik, \& Large, 1996).

\subsection{Development of land use in the study area}

The upper Lužnice basin has more than 50\% forest according to data from the 2000 CORINE Land Cover. There are no significant settlements or industrial centers in the area. Moreover, almost 25\% of the basin area is covered by a mixture of fields, meadows and perennial crops, $6.6 \%$ of the basin is comprised of meadows and pastures and $6.5 \%$ is arable land (Tab. 1).

Currently, development of land-use on the Czech and Austrian sides of the basin reflects the extensive economic character of the region. Analysis of data from the CORINE Land Cover from 1990-2000 exhibits changes in $4.9 \%$ of the area of the basin, with the most significant changes relating to the conversion of 25.23 sq. $\mathrm{km}$ arable land to meadow and pastureland. This conversion is due to the disappearance of centrally managed agriculture and a reduction in government pressure to use agricultural land. Another significant change was a 17.9 sq. $\mathrm{km}$ increase in forest area, which particularly affected the Czech side of the river basin.

\subsection{Floods in the upper Lužnice basin}

In the upper Lužnice basin, the summer floods are the dominant flood event and occur as a result of intense rains in the headwater areas of the Novohradské Mountains. Summer floods on the Lužnice typically exhibit a long run-out period, a slow progression of flood waves and a strong flow transformation (Vlasák, 2007). This is primarily due to the low slope in the central part of the basin, the high permeability of the sandy soils in the Třebon Basin, the retention of water in ponds, and the transformative effects of the river in a flat and wide alluvial floodplain. Slow runoff and high retention capacity cause the area to remain saturated after floods, which results in the Lužnice basin being highly susceptible to recurrent episodes of precipitation.

Large influence have spring floods, which are caused by the snow thaw and primarily affect the middle and lower parts of the river basin, where the thaw generally occurs over a large part of the basin as a result of the less rugged topography (Vlasák, 2006). 


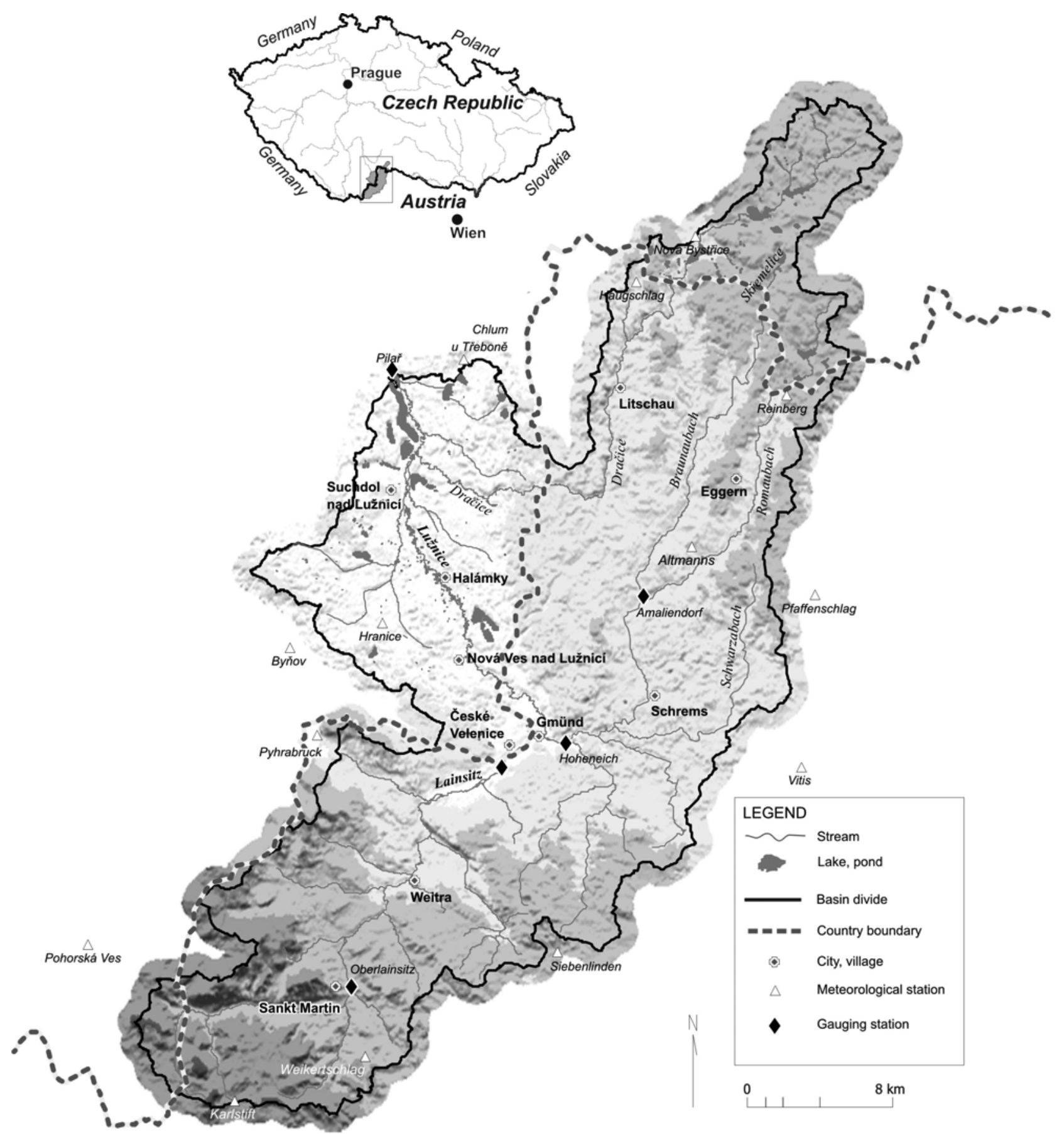

Fig. 1. Upper Lužnice Basin - Map of the study area. 
$\mathrm{T}$ a b l e 1. Change in vegetation cover in the upper Lužnice basin.

\begin{tabular}{lll}
\hline Vegetation cover & \multicolumn{2}{c}{ Percentage [\%] } \\
& Year 2000 & Year 1990 \\
\hline Peat-bog & 0.10 & 0.12 \\
Lakes & 0.74 & 0.71 \\
Wetlands and marshes & 0.77 & 0.77 \\
Low forest vegetation & 0.19 & 2.04 \\
Mixed Forest & 0.42 & 0.41 \\
Coniferous forest & 51.90 & 50.04 \\
Deciduous forest & 0.00 & 0.00 \\
Mix of agriculture and natural vegetation & 4.34 & 4.34 \\
Meadows and pastures & 6.60 & 3.94 \\
Non-irrigated arable land & 6.47 & 9.14 \\
Areas of current production & 0.15 & 0.20 \\
Road and rail network and related & 0.06 & 0.06 \\
Industrial and commercial areas & 0.07 & 0.07 \\
Scarcely settlement & 3.12 & 3.12 \\
Sports and recreation areas & 0.11 & 0.00 \\
A mixture of fields, meadows and perennial crops & 24.97 & 25.04 \\
\hline Total & 100 & 100 \\
\hline
\end{tabular}

\section{Material and methods}

\subsection{Application of HEC-HMS model}

The HEC-HMS hydrological model was chosen for use in the study. This model is a proven tool for simulating runoff that is suitable in general geographical conditions (Knebl, Yang, Hutchison, and Maidment, 2005, McColl and Aggett, 2007, Wan and Yang, 2007) and widely used in research and application practice due to its free availability.

The SCS CN method was used to calculate the volume of discharge and the associated separation into direct runoff and baseflow and the $\mathrm{CN}$ curve method (USACE, 1994) was used to calculate runoff losses. The CN curve method is one of the most popular due to the associated simplicity and ease of data input. Based on land cover (CORINE Land Cover), the values of the $\mathrm{CN}$ curves were determined based on the index of previous rainfall and soil hydrologic group (determined by the infiltration capacity of soils derived from soil maps CR $1: 50,000$ and for the Austrian part of the basin $1: 30,000)$. The $\mathrm{CN}$ curve method estimates precipitation excess as a function of cumulative precipitation, soil cover, land use, and antecedent moisture, using the following equation:

$$
P e=\frac{\left(P-I_{a}\right)^{2}}{\left(P-I_{a}\right)+S},
$$

where $P e$ - accumulated precipitation excess at time $t, P$ - accumulated rainfall depth at time $t, I a-$ the initial abstraction (initial loss) and $S$ - potential maximum retention, a measure of the ability of a watershed to abstract and retain storm precipitation. Until the accumulated rainfall exceeds the initial abstraction, the precipitation excess, and hence the runoff, will be zero.

The Clark Unit Hydrograph was used to quantify direct runoff. For this calculation, $T_{c}$ (time of concentration), $T_{\text {lag }}$ (lag time) and $R_{c}$ (retention coefficient) must be determined.

Time of concentration is the time of flow from the most hydraulically distant point in the watershed to the watershed outlet. Lag time is the time from the center of mass of excess rainfall to the hydrograph peak and was estimated as:

$$
T_{\text {lag }}=L^{0.8} \frac{(S+1)^{0.7}}{1900 \cdot \sqrt{Y}} \text { [hours] }
$$

where $L$ - maximum hydraulic length of watershed [feet], $S$ - maximum retention in the watershed estimated from $\mathrm{CN}$ curves [inches], $Y-$ atershed slope [\%]. 
The lag time may be related to time of concentration, $T_{c}$, as:

$$
T_{c}=\frac{T_{\text {lag }}}{0.6}[\text { hours }] .
$$

The basin storage coefficient, $R$, is a index of the temporary storage of precipitation excess in the watershed as it drains to the outlet point:

$$
R_{c}=A \cdot L^{B} \cdot S_{10-85}^{C},
$$

where $L$ - maximum hydraulic length of watershed [mi], $S_{10-85}$ - average watershed slope along to maximum hydraulic length of watershed between $10 \%-85 \%$ of the length [ft/mi],

$\mathrm{A}, \mathrm{B}, \mathrm{C}$ - coefficients (for $\mathrm{CZE} \mathrm{A}=80, \mathrm{~B}=0.342$, $\mathrm{C}=-0.79$ ).

The Muskingum-Cunge method was chosen to calculate channel runoff. For this method, the following parameters must be specified: the width of the channel bottom and side slope, the Manning Roughness Coefficient and the shape of the channel. The Lužnice River can be divided into three different physiographical regions and based on information about this segments the parameters were determine: for an area with springs located high in the Novohradské Mountains - shape „Trapezoidal"; the width of the channel bottom 2 meters, the Manning Roughness Coefficient 0.035; for a highlands area in Austria - shape „Trapezoidal“; the width of the channel bottom 5.5 meters, the Manning Roughness Coefficient 0.035; and for a lowland region of the Třebon basin in the Czech Republic - shape „Trapezoidal“; the width of the channel bottom 10 meters, the Manning Roughness Coefficient 0.04.

The Recession Baseflow Method was used to determine baseflow runoff. This method is designed to approximate the typical behavior observed in watershed when channel flow recedes exponentially after an event and is intended primarily for event simulation. The initial value of the derivative of the baseflow, recession constant (the ratio of baseflow at the current time to the baseflow one day earlier) and threshold runoff must be specified to use this method. The BFI (base flow index) method was used to determine the initial baseflow.

\subsection{Model calibration and validation}

The calibration and validation of a model is essential for application. Model calibration aims to determine the model parameters that result in the best agreement between modeled and measured quantities (Bedient, Huber and Vieux, 2007). Calibration is implemented using historical events with calculated values that can be validated using measured data. The goal of validation is to test derived parameters in a different time frame than the actual time of generation.

The flood of early August in 1991 served as the calibration model. This event represents a typical flood caused by strong regional summer rains, even though extraordinary peak flow values did not occur. The triggering rainfall lasted from July 31 to Aug. 4, 1991. Peak flow on the Pilar station of 60.3 $\mathrm{m}^{3} \mathrm{~s}^{-1}$ occurred on Aug. 4, 1991 at 11:00. The course of flood waves triggering precipitation throughout the basin, and hourly intensity are shown in Fig. 2.

For the model validation, the flood from August 2002, which was the largest recorded flood in the Lužnice River basin, was selected. The flood event was caused by the advancement of two strong cyclones, which on August 7-8, 2002 and August 11$-12,2002$, caused extraordinarily heavy rainfalls. The runoff response to the first phase of rainfall reached its maximum value of $285 \mathrm{~m}^{3} \mathrm{~s}^{-1}$ at the Pilař profile on August 8, 2002. The second flood wave reached significantly higher value of $498 \mathrm{~m}^{3}$ $\mathrm{s}^{-1}$ at the Pilař profile on August 13, 2002.

\subsection{Model scenarios}

Two real and two theoretical ground cover scenarios were defined to evaluate the impact of land use changes on precipitation-runoff processes. The first scenario represents the vegetative ground cover in 1990 and the second scenario corresponds to ground cover in 2000. For the third scenario, the categories of arable land, mixed pasture, fields and perennial cultivation were transformed to permanent grasslands. The fourth scenario represents forestation of all land use categories, except for bodies of water, urban areas and roads. There was an increase in area from 6.6 to $38 \%$ for permanent grassland and an increase in area from 52.3 to $96 \%$ for forestation. The scenario demonstrating an increase in forestation is unrealistic but was included as an extreme variant with the highest retentive effect.

All scenarios were modelled for four rainfall events with recurrence periods of 10,20,50 and 100 years. The design of rainfall events that lasted one day each was determined by the lognormal 
distribution of the maximum daily rainfall for the time period from 1981 to 2004. In all cases, the computational period was one hour and a hyetograph in the shape of an isosceles triangle was used to demonstrate the distribution of precipitation during the simulation over 24 hours. Rainfall for the river basin and for individual sub-basins was de- termined by the Thiessen polygons method from 13 stations.

Evaporation and transpiration were not considered. Hydrographs of individual scenarios and runoff summary tables were used to compare the results of modelling to gauge profiles in the subbasin.

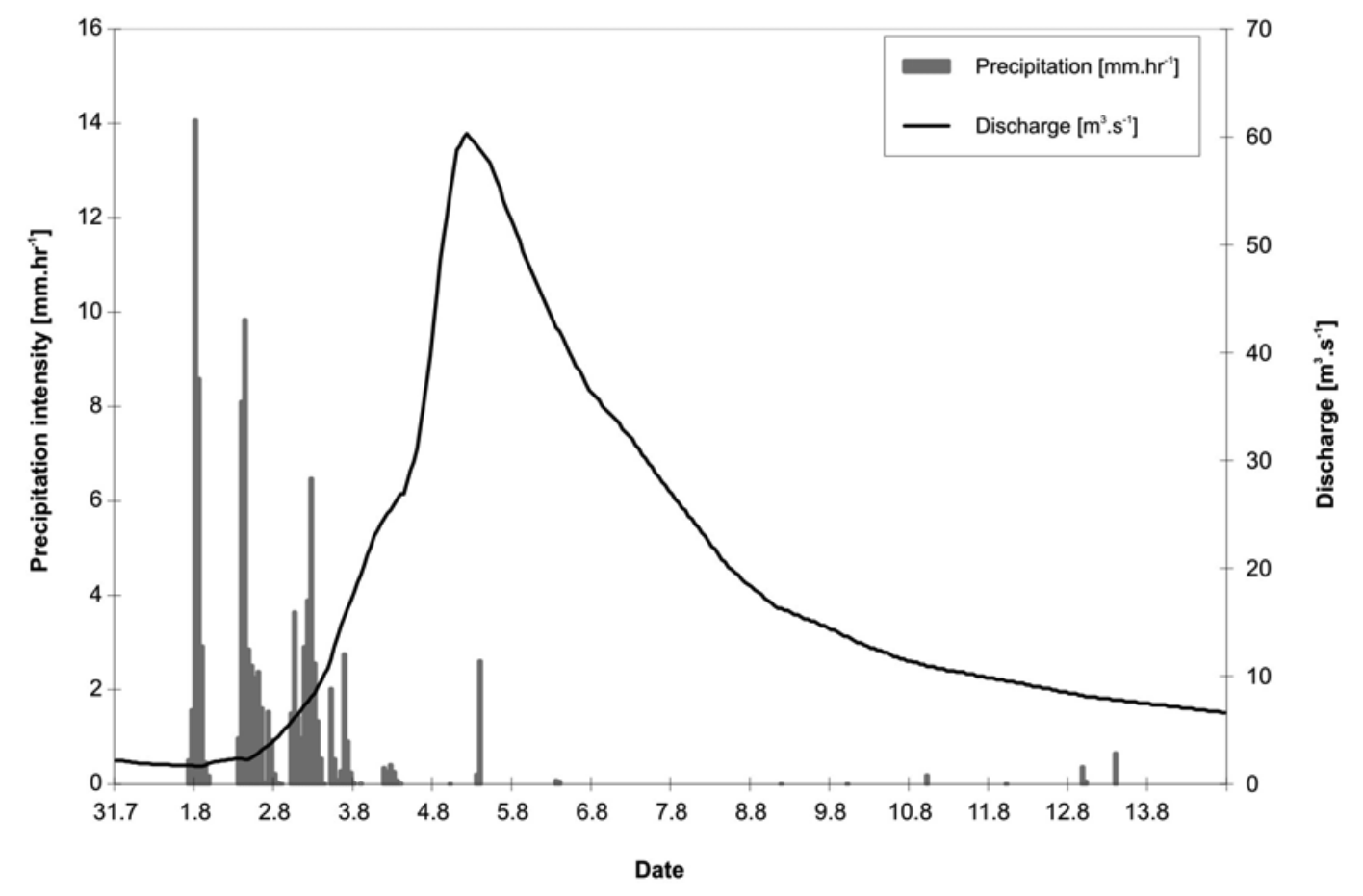

Fig. 2. Hourly intensity of precipitation and flood runoff hydrograph from July 31, 1991, to August 13, 1991.

\subsection{Input data}

The CORINE Land Cover Database for 1990 and 2000 was chosen for analysis of land use in the study area, including the Austrian part of the basin. The EEA portal $(E E A, 2008)$ served as the data source and interpretation key. The Czech Hydrometeorological Institute (CHMI, 2008) and the Austrian Federal Ministry of Agriculture, Forestry, Environment and Water Management (BMLFUW, 2008) provided the hydrological and meteorological data for setup, calibration and validation of the model.

To verify the homogeneity of the rainfall data, the double mass curve method using comparisons to two neighboring stations was employed. The first station served as the monitoring station and the latter, as the control station. Average rainfall for the river basin and for individual sub-basins was determined by the Thiessen polygons method, where the rainfall data from the stations were converted to a uniform time interval of 1 hour. In total, 13 stations were used to divide the river basin into Thiessen polygons.

For stream discharge data, the average daily discharge from the stream gauge station at Pilař (CHMI, 2008) and from the stations Oberlainsitz, Hoheneich, Amaliendorf and Ehrendorf (BMLFUW, 2008) were available.

The geodatabase DIBAVOD ( $V U V, 2008)$ was used as a source for general topographic data for the river network. The contour model DMÚ-25 (VTOPU, 2006) was used to compile a digital terrain model for the Czech Republic and the model provided by VÚV TGM in Prague (VUV, 2008) was used for the Austrian part of the river basin. Contour lines with intervals of 5 metres (VTPOU, 2006) were used as input data to create a digital terrain model for the Czech Republic and contour lines with vertical intervals of 10 meters was used for the Austrian territory ( $V U V, 2008)$. 


\section{Results}

\subsection{Model calibration and validation}

During the calibration of the first simulation, an initial set of parameters was derived from the basic physiographic characteristics of the basin with land cover representative of 1990. As the criterion for automated parameter optimization the method of minimum differences of hydrograph peaks was used while the $\mathrm{CN}$ and Muskingum parameters were selected for optimization. The speed of the wave progress through the channel was reduced through automatic optimization (originally specified values based on the passage of the wave through the channel corresponded to the flood wave of 2002). Automatic optimization resulted in the reduction of $\mathrm{CN}$ parameters on average $20 \%$ (min. $17.6 \%$, max. $29 \%$ ). The $\mathrm{CN}$-curve parameters of Ia (initial loss) and $T c$ (time of concentration) have been recalculated according to these new values. Before the calibration the values of Ia ranged from $4.5 \mathrm{~mm}$ to $34 \mathrm{~mm}$ and after the calibration the values of Ia ranged from $19.3 \mathrm{~mm}$ to $57.2 \mathrm{~mm}$. The values of Tc had before the calibration average value 25 hours and after the calibration had average value 36.4 hours. By regression analysis the values of the time of concentrations is most depend on maximum hydraulic length of watershed $(r=0.8)$, then to the watershed slope $(r=0.5)$ and the minimum dependence is on the changes of the $\mathrm{CN}$ values $(r=0.3)$.

Furthermore, the recession constant and threshold value parameters were manually recalculated based on several simulations. The recession constant was set to 0.75 and the threshold value was set at 0.4 .

The calibration results (Fig. 3) exhibit good correspondence between the simulated and observed discharge curves. The Nash-Sutcliff coefficient reached a value of 0.96 . The percentage of volume error was $2.28 \%$, which means that the volume of the simulated wave was larger than the actual wave. The difference between the simulated and real peak flow is $0.8 \mathrm{~m}^{3} \mathrm{~s}^{-1}$. Both flood waves reached maximum level at 11 am on August 4, 1991. The optimization criteria values obtained indicate that the calibration of the rainfall-runoff model was successful.

The flood of August 2002, which was the largest recorded flood in the Lužnice basin, was chosen as the validation model. The flood event was caused by the advancement of two major low-pressure systems, which brought exceptionally intense precipitation on August 6 - 7 and 11 - 12, 2002. Total rainfall measured at six stations for the period of August 5 - 13, 2002 exceeded $300 \mathrm{~mm}$.

The runoff from the first wave of precipitation peaked on the Pilař profile at $285 \mathrm{~m}^{3} \mathrm{~s}^{-1}$ on August 8 , 2002. Although the total rainfall during the second wave of floods was lower, there was a significantly higher peak value on the Pilař station profile of $498 \mathrm{~m}^{3} \mathrm{~s}^{-1}$ on August 13, 2002, due to the high saturation level in the basin (Fig. 4).

Validation of the calibrated model parameters with an independent series of input data was performed for the period from August 5 to August 18, 2002. This is the so-called "differential split-sample test" because there was dissimilar vegetation cover in the upper Lužnice than in previous models during this period. Therefore, input parameters were changed to match land cover in 2000 and for the $\mathrm{CN}$-curves was used optimization from the previous calibration.

The graph in Fig. 5 demonstrates the relatively good visual match between the shape of the simulated and actual discharge curves. The NashSutcliff coefficient is 0.91 , and the percentage of volume error is $9.8 \%$. The total volume of the simulated waves was greater than the actual total volume.

The difference between the first simulated and actual peak discharge is $28.6 \mathrm{~m}^{3} \mathrm{~s}^{-1}$, which corresponds to a disparity of $10 \%$. The simulated flood wave reached a maximum at 14:00 hrs on August 8, 2002 , and thus arrived two hours later than the actual wave.

The second simulated wave peaked at 20:00 hrs on Aug. 13, 2002, at $501.1 \mathrm{~m}^{3} \mathrm{~s}^{-1}$, which is approximately an hour earlier than the observed time. The peak discharge of these simulated waves was approximately $1 \%$ higher than the observed discharge waves.

During the second flood wave, runoff entered the sand pit Cep located outside the riverbed and thus partially bypassed the Pilař gauging station. Therefore, the course of the flood from the records at the Pilař station could not be directly assessed. The volume of the flood wave was estimated by hydraulic calculation of the maximum surface area and extent of inundation, which was verified by modelling to approximate actual values (Vlasák, 2006). 


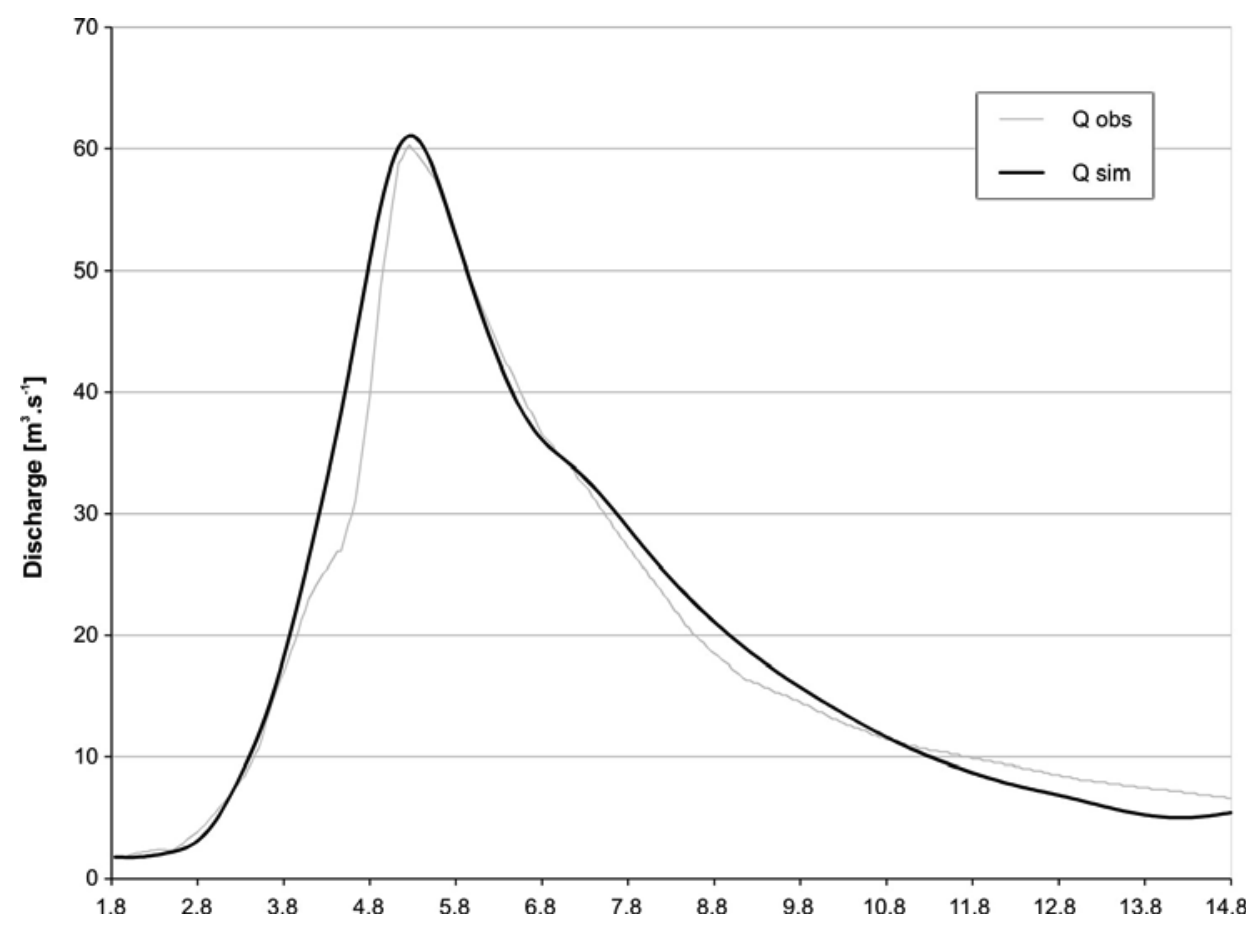

Fig. 3. Simulated and observed hydrograph from the Pilař gauging station profile in August 1991.

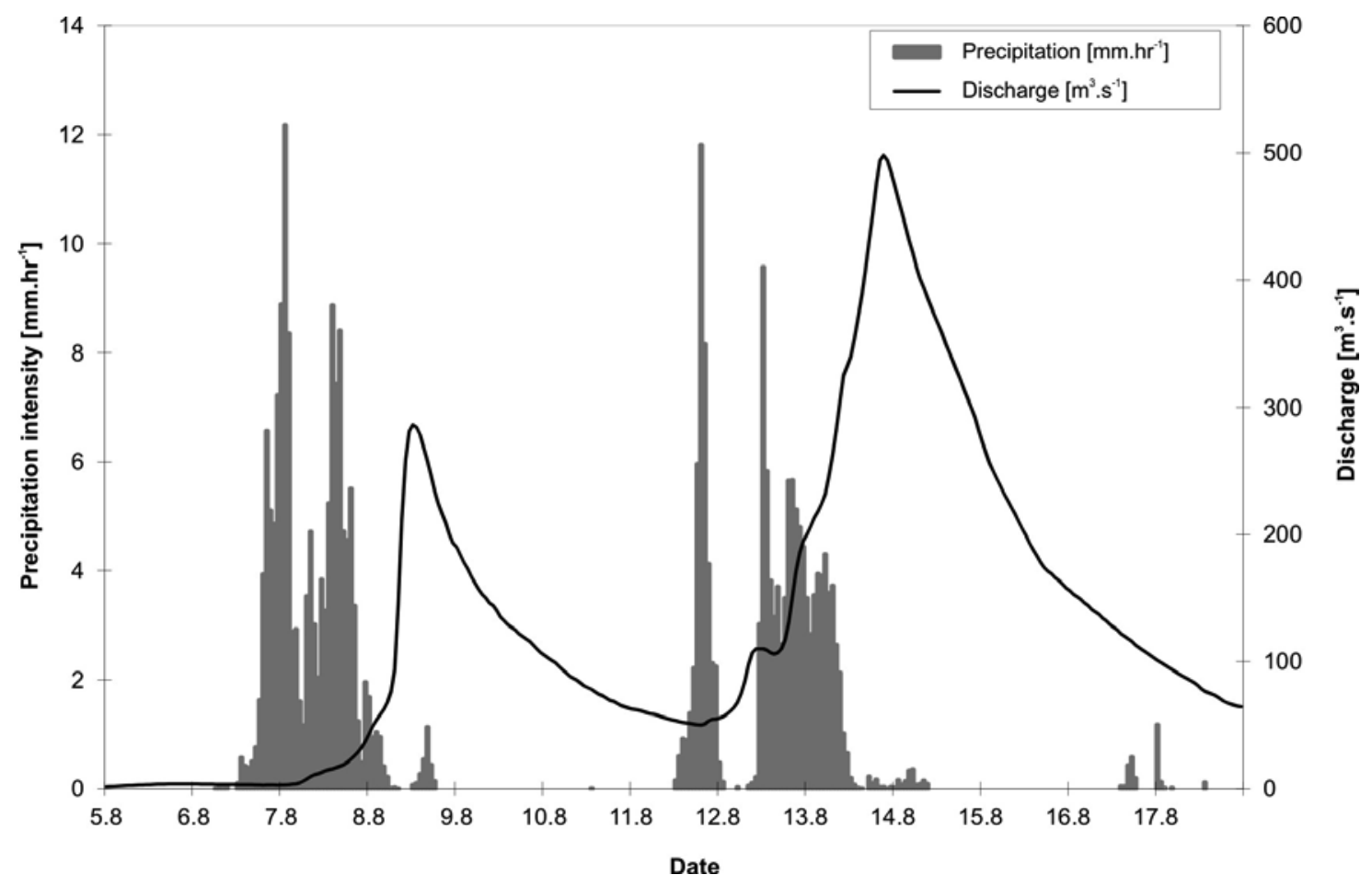

Fig. 4. Hourly intensity of precipitation and flood runoff hydrograph from August 5-18, 2002. 


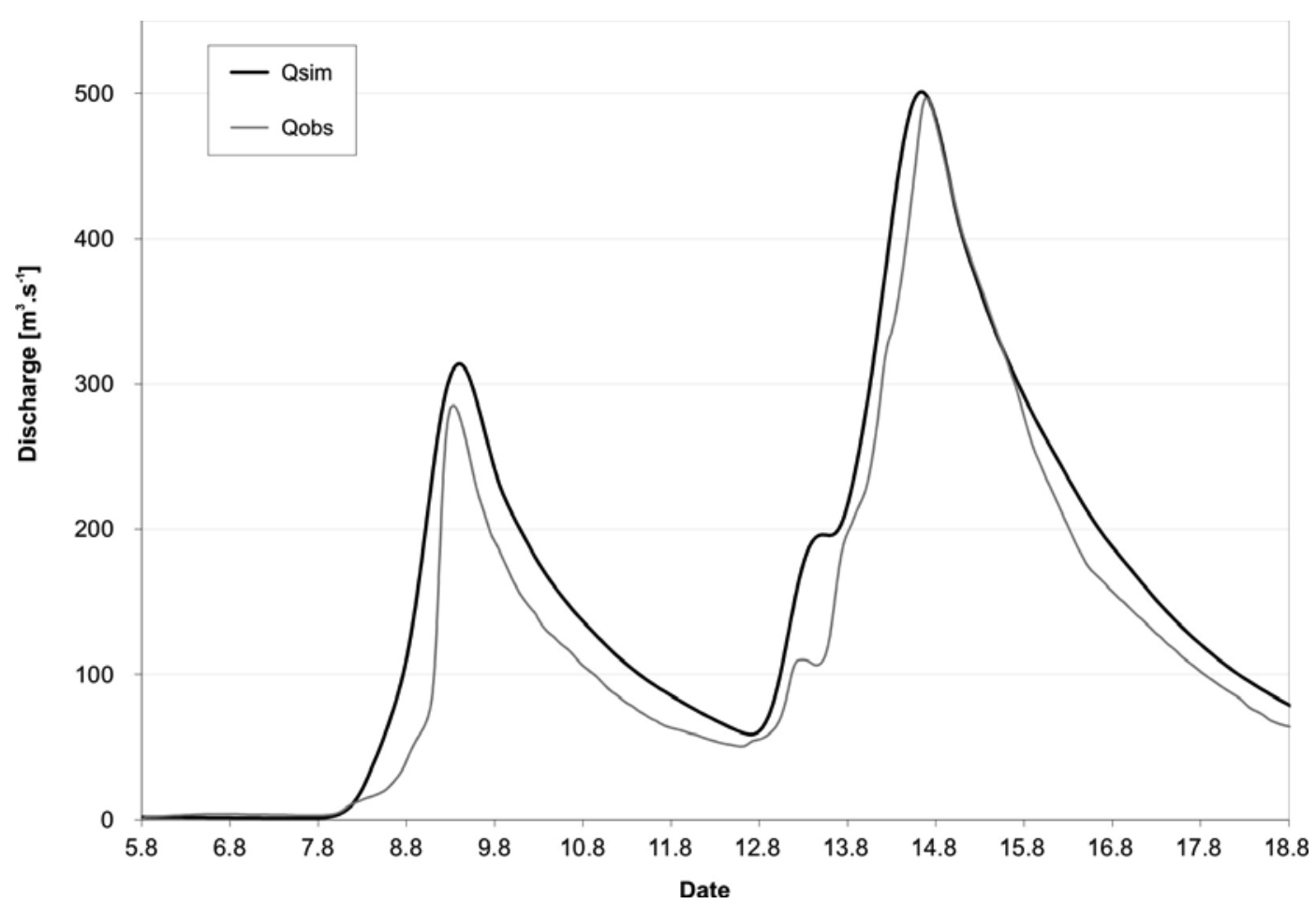

Fig. 5. Simulated and observed hydrograph from the Pilař gauging station profile from August 2002.

$\mathrm{T}$ a b l e 2. Selected parameters of simulated flood waves at the Pilar̆ gauging station.

\begin{tabular}{|c|c|c|c|c|c|c|c|c|}
\hline \multirow[t]{2}{*}{ Scenario } & \multicolumn{2}{|c|}{$N=100$} & \multicolumn{2}{|c|}{$N=50$} & \multicolumn{2}{|c|}{$N=20$} & \multicolumn{2}{|c|}{$N=10$} \\
\hline & $\begin{array}{l}Q_{\max } \\
{\left[\mathrm{m}^{3} \mathrm{~s}^{-1}\right]}\end{array}$ & $\begin{array}{l}V_{\text {celk }} \\
{\left[10^{3} \mathrm{~m}^{3}\right]}\end{array}$ & $\underset{\left[\mathrm{m}^{3} \mathrm{~s}^{-1}\right]}{Q_{1}}$ & $\begin{array}{l}V_{\text {celk }} \\
{\left[10^{3} \mathrm{~m}^{3}\right]}\end{array}$ & $\begin{array}{l}Q_{\max } \\
{\left[\mathrm{m}^{3} \mathrm{~s}^{-1}\right]}\end{array}$ & $\begin{array}{l}V_{\text {celk }} \\
{\left[10^{3} \mathrm{~m}^{3}\right]}\end{array}$ & $\begin{array}{l}Q_{\max } \\
{\left[\mathrm{m}^{3} \mathrm{~s}\right.}\end{array}$ & $\begin{array}{c}V_{\text {celk }} \\
]\left[10^{3} \mathrm{~m}^{3}\right]\end{array}$ \\
\hline Landcover 1990 & 85.5 & 25258.7 & 62.9 & 18692.1 & 41.7 & 12482.2 & 24 & 7257.3 \\
\hline Landcover 2000 & 81.3 & 24026.3 & 59.5 & 17704.9 & 39.2 & 11768.2 & 22.5 & 6837.2 \\
\hline Grassing & 75.4 & 22354.1 & 54.9 & 16381.4 & 35.9 & 10827.6 & 20.6 & 6760 \\
\hline Afforestation & 59.8 & 17878.3 & 42.7 & 12906.1 & 27.5 & 8449.8 & 16.4 & 5081.7 \\
\hline
\end{tabular}

\subsection{Simulation of land use scenarios for different extreme levels of precipitation}

Results for the Pilař gauging station profiles are summarized in Tab. 2 and Fig. 6.

Discharge hydrographs for individual land use change scenarios with an average 100 year total precipitation recurrence have a very similar pattern in the Pilař gauging station profiles. There was a reduction of $4.9 \%$ in the peak discharge of the flood wave in the 2000 scenario (compared to 1990) and no delay in the flood wave. The volume of the flood wave also exhibited a decrease by $4.9 \%$. In the scenario with partial conversion of the basin to grassland, there was an $11.8 \%$ decrease in peak discharge compared to 1990 and an $11.5 \%$ decrease in the flood wave volume. A large difference in the maximum discharge rate is particularly evident in the forestation scenario with an actual decrease of $30 \%$ and peak flow delay by one hour.

The reduction in the peak discharge of the flood wave corresponding to 10 years of precipitation between 1990 and 2000 reached $1.5 \mathrm{~m}^{3} \mathrm{~s}^{-1}$ or $6.5 \%$. There was no delay in the flood waves and a $5.8 \%$ decrease in the flood wave volume. In the partial conversion of the basin to grassland scenario, there was a decrease in peak discharge compared to 1990 of $14.2 \%$ and the volume of the flood waves decreased by $12.5 \%$. The most significant difference in maximum discharge rate is also evident in the forestation scenario with a $32 \%$ reduction. Furthermore, there was no flood wave delay in this scenario.

Changes in peak discharge levels in scenarios with real changes in land use are small for all precipitation variations. In the scenario corresponding 
to conditions in 2000 , there was a decrease in the peak Pilař gauging station profiles compared to 1990 of $4.9 \%$ during precipitation with an average period of recurrence of 100 years to $6.3 \%$ during precipitation with an average recurrence of 10 years. The theoretical effect of the conversion of arable land to grassland compared to actual changes is approximately double in all variations.

The most striking differences in the effect of land cover changes are the input levels of precipitation in the theoretical forestation scenario (Fig. 7). The difference is at least $30 \%$ in all cases between the conditions of $96 \%$ forest coverage in the basin area and the situation in 1990 (51\% forest coverage of the basin). The biggest difference occurs at a precipitation level with an average recurrence of 20 years when the peak discharge decreased by $34 \%$. The decrease was $30 \%$ for precipitation with an average recurrence at 100 years.
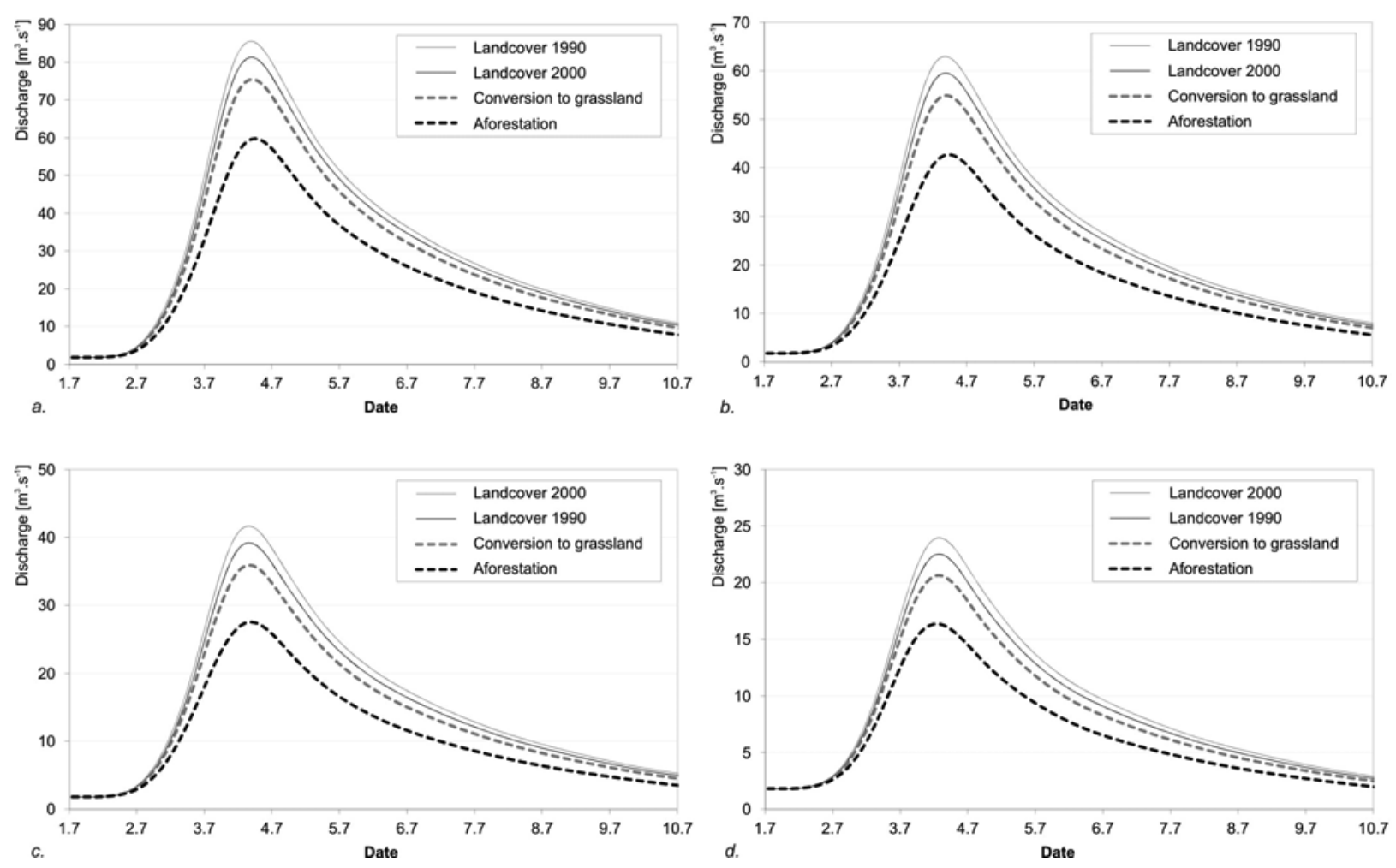

Fig. 6. Comparison of decreases in peak levels for the various scenarios at precipitation extremes.

\section{Discussion}

Comparison of the differences in peak discharge values reached during individual variants of basin land use and scenarios of precipitation levels confirmed general assumptions on the effect of landuse on runoff (e.g., Calder, 1993). The importance of structural changes in land cover slightly decreased with increasing extremity of the event. Differences between individual scenarios were not significant.

The key to an accurate interpretation of the modelling results is an understanding of the sources of uncertainty that occur in various phases of preparation and calibration of the models.
The principal source of uncertainty in the application of the HEC-HMS model to the upper Lužnice basin is the considerable heterogeneity and extent of the assessed territory.

In the case of the subject area, a problematic element is the extension into the territories of two states. This leads to issues with the consistency and thoroughness of data that is acquired in dissimilar structures at different levels of detail and with varying degrees of accessibility.

Regarding the upper Lužnice basin, the key problem is the temporal and spatial accuracy of rainfall data. Information regarding precipitation is obtained from a network of ground observation stations that provide point-oriented data. A refinement would be the use of radar estimates available in 


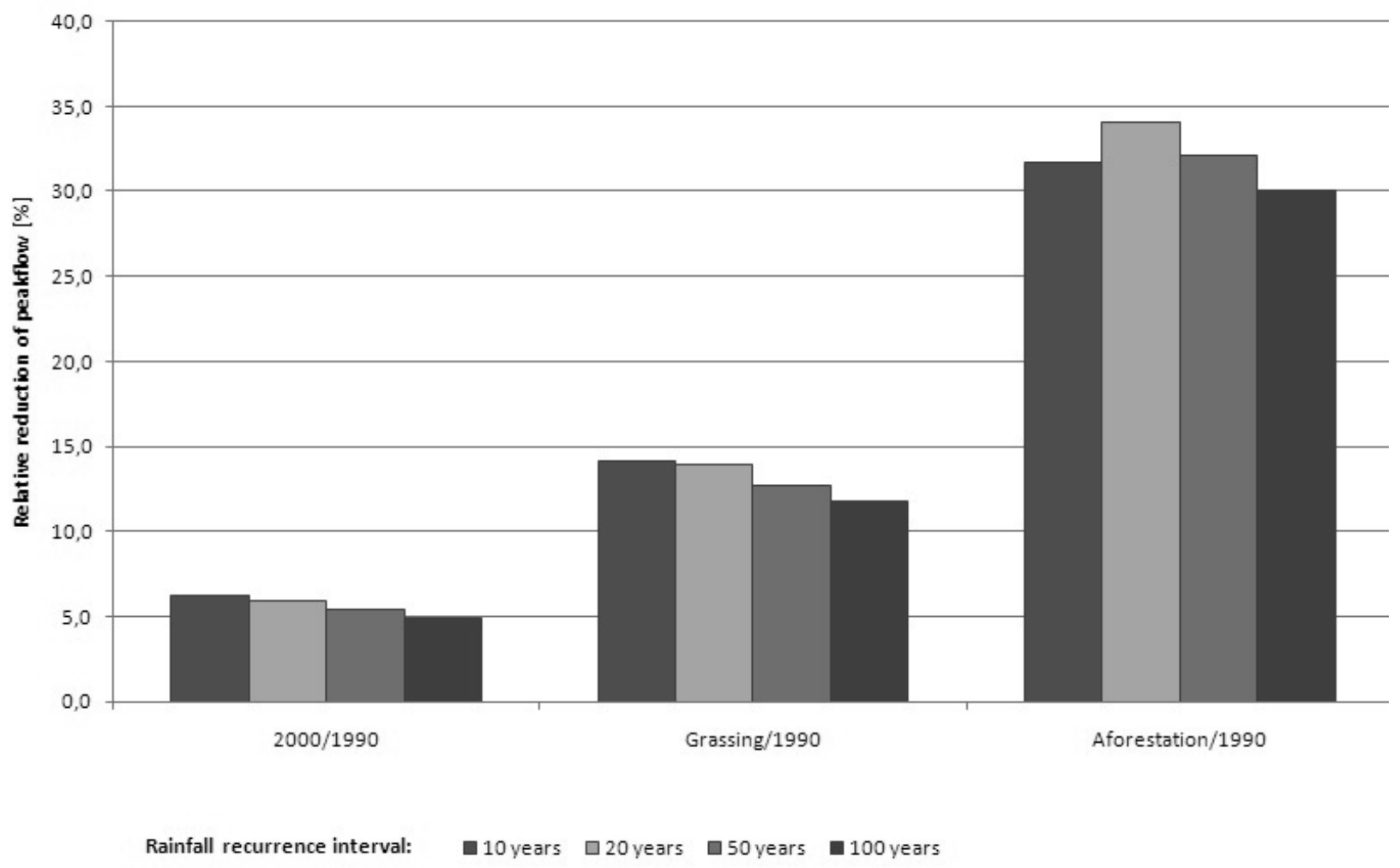

Fig. 7. Simulated flow curves at the Pilař gauging station profiles for individual scenarios of postulated precipitation with a recurrence of $100(\mathrm{~A}), 50(\mathrm{~B}), 20(\mathrm{C})$, and $10(\mathrm{D})$ years.

small temporal increments (minute increments) that would permit a detailed spatial resolution of precipitation (1x1-km grid) (Daňhelka, 2003). A change in the temporal increment can also influence the resulting simulated discharge. In the case of the upper Lužnice basin model, one hour was chosen as the optimal temporal increment given the available data.

The important elements of the basin include the soil and associated properties. The SCS CN method was used in this case. The most significant issue was obtaining data about hydrological soil groups. While there are several ways to obtain this information in the Czech Republic, such as digital maps of the soil hydropedological characteristics (Novák, Vopravil, 2003) or from the BPEJ based on the methodology of Janeček (2005), similar data for the Austrian part of the basin are unavailable. Therefore, data from soil maps with similar scales processed for CR and Austria were used and the data was refined based on soil property profiles for the Austrian territory (infiltration).

The resulting hydrograph is also significantly affected by the initial soil saturation setting, which can be determined by establishing the $\mathrm{CN}$ values. The $\mathrm{CN}$-curve is adjusted based on the previous five-day rainfall totals at three levels. The simulations were performed for conditions of average initial saturation (PVP II). Even if sufficient for design purposes, this model would have to be calibrated to further refine the simulated hydrograph with regard to the influence of water content in the soil.

Further uncertainties arise when determining the channel characteristics that are necessary to model the flood wave advance through the river network. For individual sections of the stream, these parameters include the length, slope, Manning Roughness Coefficient, bottom width, inclination, and representative riverbed cross section. The associated uncertainty arises in estimating the roughness coefficient and cross section of the channel. Crosschannel profiles can be measured in the field, but this was not possible given the size of the basin. Therefore, calibration of these values is appropriate to more accurately simulate the movement of flood wave through the channel.

Although evapotranspiration and interception data could be used in this model, these factors were not considered because they are not easily accessible, were not present at the beginning of the rainfall-runoff process, and are of minor importance in 
flood events. Although this led to a certain degree of simplification, the resulting runoff was not significantly influenced.

The basic source of uncertainty in runoff modelling is the generalization of complex processes in the natural environment. The simplification of processes and the selection of key factors in the model led to the attenuation of other aspects that may play an important role in runoff process at different scales, but will not effectively simulate the selected process.

For example, this relates to the calculation of runoff from forest areas in the applied HEC-HMS model, which is particularly important in the basin forestation scenario and exhibits the highest transformational effect. Neither commonly used models nor the available data take into account factors that play a basic role in forming runoff at the lowest spatial level. These include the species and age composition of the forest, the health of the forest, the density and layout of the road network, the existence of a drainage network, and the compaction of soil due to heavy machinery. These factors may significantly accelerate runoff in the case of heavy precipitation (Hais, 2003, Tesař et al., 2004). Expressing these factors is difficult given the level of spatial and conceptual generalization in the model; moreover, relevant data are not available for their quantification. The generalization of these factors in the applied model probably leads to a greater transformational effect of forest cover than is realistic.

\section{Conclusions}

Results from the simulation of four scenarios of land cover impact and different input levels of precipitation on the discharge response in the upper Lužnice basin clearly demonstrates the limits of the effects of land cover for mitigation of extreme runoff events.

Simulation of the impact of ongoing land use changes in theoretical development scenarios has revealed that the rather significant reduction in arable land since 1990 had only a minor effect on the decrease in peak discharge values during floods of approximately $5 \%$.

The overall potential for landscape exploitation for transformation of runoff in the assessed basin is high, mainly due to the large extent of forests and grassland. However, the modelling results indicate limits of the transformation effect for efficient mitigation of flood events.
The model confirmed the declining influence of the land use character on the transformation of runoff with increasing event extremity. The greatest differences are evident in the events induced by 10 respective 20-year precipitation recordings.

The theoretical landscape change scenarios suggest that any eventual reserves in the utilization of the natural potential for transformation of flood discharges in the basin of the upper Lužnice are not significant. However, the scenario of complete forestation at all levels of precipitation demonstrates the significant dampening effect of the forest of up to $34 \%$ of the present value for the course of the flood wave. However, this scenario is not realistic and represents a theoretical reference maximum transformation potential that the landscape could provide for flood mitigation.

Conversion of agricultural land to grassland is a scenario that reflects the real situation in a longterm perspective. Full conversion of agricultural land to grassland could theoretically bring result in a $10-14 \%$ reduction of peak levels depending on the event extremity. However, such a development is also unrealistic. Despite growing pressure for the protection of nature, complete abandonment of agricultural land cannot be expected. A further decrease in the intensity of agricultural activity could result in a decrease in peak levels on the order of a couple of percentage points.

The simulation presented herein demonstrates that the analyzed basin is sensitive to changes in land cover. Even relatively small interventions in the conditions represented by each landscape can cause significant fluctuations in the discharge regime.

Acknowledgments. This research was funded by the Research Scheme MSM 0021620831, “Geographical Systems and Risk Processes in the Context of Global Changes and European Integration"' and the project QH82078 "Water retention in floodplains and the measures of its increase".

\section{REFERENCES}

BECKER A., SERBAN P., 1990: Hydrological models for water resources system design and operation. WMO Operational Hydrological Report 34. World Meteorological Organization, Geneva.

BEDIENT, P. B., HUBER W. C., VIEUX B. E., 2007: Hydrology and Floodplain Analysis (4 ed., p. 816). Prentice Hall, London.

BRATH A., MONTANARI A., MORETTI G., 2006: Assessing the effect on flood frequency of land use change via hydrological simulation (with uncertainty). J. Hydrol., 324, $1-4,141-153$. 
BMLFUW, 2008: eHYD - Hydrographische Messstellen. http://geoinfo.lfrz.at (15. 7. 2008).

CALDER I., 1993: Hydrologic effects of land-use change. In D. Maidment, Handbook of Hydrology. McGraw-Hill, New York

CHMI, 2008: Precipitation and runoff database. CHMI, Prague.

DAŇHELKA J. a kol., 2003: Posouzení vhodnosti aplikace srážko-odtokových modelů $\mathrm{s}$ ohledem na simulaci povodňových stavů pro lokality na území ČR. ČZU, Praha.

EEA, 2008: CORINE Landcover database. EEA, Copenhagen. http://www.eea.europa.eu/data-andmaps/data/corine-landcover-clc1990-250-m-version-9-2007. (3. 11. 2008.)

HAIS M., 2003: Changes in Land Cover Temperature and Humidity Parameters Resulting from Spruce Forests Decay in the Centre of the Sumava National Park. Acta Universitatis Carolinae - Geographica XXXVIII, 95-105.

HELLWEGER F. L., MAIDMENT D. R., 1999: Definition and Connection of Hydrologic Elements using Geographic Data. J. Hydrolog. Engng, 4, 1, 10-18.

JANEČEK M. a kol., 2005: Ochrana zemědělské půdy před erozí. ISV, Praha.

KNEBL M. R., YANG Z., HUTCHISON K., MAIDMENT D. R., 2005: Regional scale flood modeling using NEXRAD rainfall, GIS, and HEC-HMS/RAS: a case study for the San Antonio River Basin Summer 2002 storm event. J. Environmen. Mngnt., 75, 4, 325-336.

KULHAVÝ Z., KOVÁŘ P., 2002: Využití modelů hydrologické bilance pro malá povodí. VÚMOP, Praha.

McCOLL C., AGGETT G., 2007: Land-use forecasting and hydrologic model integration for improved land-use decision support. J. Environment. Mngnt, 84, 4, 494-512.

NAEF F., SCHERRER S., WEILER M., 2002: A process based assessment of the potential to reduce flood runoff by land use change. J. Hydrol., 267, 1-2, 74-79.
NOVÁK P. a kol., 2003: Zpracování digitálních map hydropedologických charakteristik půd České republiky. [Závěrečná zpráva a výstup 02 projektu QD 1368.] VÚMOP, Praha.

PRACH K., JENÍK J., LARGE A. R., 1996: Floodplain ecology and management. The Luznice river in the Trebon biosphere reserve, Central Europe. SPB, Amsterdam.

TESAŘ M., ŠíR M., ZELENKOVÁ E., 2006: Influence of vegetation cover on thermal regime of mountainous catchments. Biologia. 61/Suppl.19. S311-S314. DOI: 10.2478/s11756-006-0179-5

TU M., HALL M. J., DE LAAT P. J., DE WIT M. J., 2005: Extreme floods in the Meuse river over the past century: aggravated by land-use changes? Physics and Chemistry of the Earth, Parts A/B/C, 30, 4-5, 267-276.

VLASÁK T., 2006: Přehled a klasifikace povodní na Lužnici. In J. Langhammer, Změny krajiny jako ovlivňující faktor průběhu a projevů extrémních povodní. PřF UK, Praha, pp. $37-45$.

VLASÁK T., 2007: Povodňové režimy Otavy a Lužnice. In J. Langhammer, Změny $\mathrm{v}$ krajině a povodňové riziko. (pp. 105-114.) PřF UK a MŽP ČR, Praha.

VTOPU, 2006: DMU-25 Digital elevation model geodatabase. VTOPOU, Dobruska.

VUV, 2008: DIBAVOD. Digital Water Management Map. VUV TGM, Prague. http://heis.vuv.cz/. (Accessed 5. 9. 2009.)

WAN R., YANG G., 2007: Influence of land use/cover change on storm runoff-A case study of Xitiaoxi River Basin in upstream of Taihu Lake Watershed. Chinese Geographic. Sci., 17, 4, 349-356.

Received 28 January 2011 Accepted 19 October 2011 